\title{
POLA KOMUNIKASI KELOMPOK AGAMA DALAM PENCEGAHAN PENYEBARAN UJARAN KEBENCIAN DI KECAMATAN MEDAN POLONIA PADA PEMILIHAN PRESIDEN TAHUN 2019
}

\author{
Oleh: \\ Elok Perwirawati ${ }^{1)}$, \\ Prietsaweny Riris T Simamora ${ }^{2)}$, \\ dan Lestari Victoria Sinaga ${ }^{3}$ \\ Universitas Darma Agung, Medan 1,2,3) \\ E-mail : \\ $\frac{\text { elokperwirawati@yahoo.com }}{\text { wenny.debataraja@gmail.com }}^{1 \text {, }}$, \\ dan thary_vs@yahoo.co.id ${ }^{3)}$
}

\begin{abstract}
This research was inspired by many hate speech cases on social media that massively occurred ahead of the presidential election in 2019. The purpose of this study was to determine the communication patterns of religious groups in preventing the spread of hate speech and the group communication process carried out by religious leaders towards their groups about preventing the spread of hate speech in Medan Polonia District. This research uses a qualitative descriptive approach. The subjects of this study are religious leaders and members of their groups in Medan Polonia District. The sampling technique is by purposive sampling. The results showed that each religious group (Hindu, Protestant Christian, Buddhist and Islamic) had different communication patterns one to another. There are various ways conveyed by the religious leaders in minimalizing their religious members in expressing hate speech in social media. (1) Hindu religious groups tend to have relatively closed network communication networks in terms of politics to avoid the disunity the Hindu's fellow and also urge their groups to enhance their group mutual respect. (2) The Buddhist group, in its worship process, did not touch the political issues and prefer to discuss issues of security and the economy. (3)Contastively, an open and active communication network is easily found in Christian groups who are oftenly tend to accommodate their group's development with circulation of hate speech on social media, for example by utilizing whatsapp applications, and discussed it in prayer groups. (4) However, religious leader of Islamic religious groups provide themselves as filters in their network communication to avoid any communication containing hate speech so that for his group religious leaders become role models / patrons to behave.
\end{abstract}

Keywords: Communication Patterns, Religious Groups, Hate Speeches

\begin{abstract}
ABSTRAK
Penelitian ini terinspirasi dari banyaknya kasus ujaran kebencian di media sosial yang terjadi secara massif menjelang pemilihan presiden (pilpres) tahun 2019. Tujuan penelitian ini adalah untuk mengetahui pola komunikasi kelompok agama dalam pencegahan penyebaran ujaran kebencian dan proses komunikasi kelompok yang dilakukan oleh pemuka agama terhadap kelompoknya tentang pencegahan penyebaran ujaran kebencian di Kecamatan Medan Polonia. Penelitian ini menggunakan pendekatan deskriptif kualitatif. Subjek penelitian ini adalah pemuka agama dan anggota kelompoknya di Kecamatan Medan Polonia. Teknik pengambilan sampel dengan cara purposive sampling. Hasil penelitian menunjukan
\end{abstract}


bahwa setiap kelompok agama (Hindu, Kristen Protestan, Budha dan Islam) memiliki pola komunikasi yang berbeda satu sama lain. Ada perbedaan cara penyampaian pemuka agama kepada kelompoknya dalam meminimalisir pengaruh ujaran kebencian yang beredar di media sosial. Kelompok Agama Hindu cenderung memiliki jaringan komunikasi yang relatif tertutup dalam hal politik untuk menghindari perpecahan sesama umat hindu dan menghimbau kelompoknya untuk lebih meningkatkan perasaan saling menghargai. Kelompok Agama Budha dalam proses ibadahnya tidak menyinggung masalah politik dan lebih membahas masalah keamanan dan perekonomian. Jaringan komunikasi yang lebih terbuka dan aktif lebih terlihat dalam kelompok Agama Kristen yang sangat mengakomodir perkembangan kelompoknya dalam menghadapi banyaknya ujaran kebencian yang beredar di media sosial, misalnya dengan memanfaatkan aplikasi whatsapp, dan dibahas dalam kelompok doa. Sementara jaringan komunikasi dalam kelompok Agama Islam,menjadikan pemuka agama sebagai filter dalam menyaring pesan-pesan yang berisikan ujaran kebencian sehingga bagi kelompoknya pemuka agama menjadi panutan untuk bersikap.

Kata Kunci :Pola Komunikasi, Kelompok Agama, Ujaran Kebencian.

\section{PENDAHULUAN}

Beberapa indikator keberhasilan pembangunan di Indonesia adalah adanya upaya pengentasan kemiskinan, menurunnya pengangguran, dan menurunya masalah kesehatan. Namun semua program pembangunan tersebut tidak akan dapat terealisasikan dengan baik dan sesuai sasaran jika tidak terdapat partisipasi langsung dari masyarakat. Salah satu bentuk partisipasi masyarakat dalam pembangunan adalah berperan aktif dalam pembangunan politik. Bagi bangsa Indonesia yang sangat plural, masalah pembangunan politik sebenarnya menjadi agenda politik yang terus menjadi perhatian demi tercapainya tatanan kehidupan politik yang lebih demokratis pada masa yang akan datang. Partisipasi politik merupakan kegiatan seseorang atau sekelompok orang untuk ikut serta secara aktif dalam kehidupan politik yaitu dengan jalan memilih pemimpin negara yang mana kedepannya secara tidak langsung akan mempengaruhi setiap program kerja dan kebijaksanaan pemerintah termasuk kebijakan dalam hal pengentasan kemiskinan berbasis pemberdayaan masyarakat.

Permasalahannya adalah bagaimana ketika masyarakat justru bersikap apatis terhadap calon pemimpin negara ini dan isu-isu politik yang ada. Apatisme memang bukan hal baru dalam panggung perpolitikan di Indonesia. Meskipun saat ini merupakan eranya keterbukaan informasi, namun masih banyak masyarakat yang tidak paham dengan situasi perpolitikan di Indonesia. Bagi sebagian masyarakat Indonesia, politik adalah sesuatu yang buruk dan lebih parahnya lagi, kontestasi politik Indonesia saat ini banyak dibumbui oleh kampanye hitam, berita hoax dan ujaran kebencian yang membuat wajah perpolitikan di Indonesia semakin memprihatinkan.

Ujaran kebencian merupakan salah satu bentuk alat provokatif bersifat destruktif yang. banyak ditemukan sejak media sosial menjadi bagian dari gaya hidup modern. Ujaran kebencian pertama kali terjadi secara massif pada penyelenggaraan pemilihan umum Presiden di tahun 2014, kemudian semakin memanas selama Pilkada DKI Jakarta tahun 2017 dan masih akan terus meningkat menjelang agenda kontestasi politik pemilihan Presiden Tahun 2019 mendatang. Hal ini disebabkan ujaran kebencian masih menjadi salah satu strategi kampanye yang paling jitu untuk menyerang dan menjatuhkan lawan atau pesaing politik.

Permasalahan yang paling krusial adalah mereka yang menyebarkan ujaran kebencian seakan tidak peduli akan dampak negatif yang dihasilkan dari penyebaran 
tersebut. Ujaran kebencian menjadi salah satu sumber konflik yang perlu untuk diantisipasi, karena akan berdampak besar pada pola pikir maupun sikap seseorang yang dapat memicu kekerasan yang berujung kepada disintegrasi bangsa, tindakan intoleransi dan diskriminasi apalagi kondisi bangsa Indonesia dengan heterogenitas yang tinggi cenderung memiliki emosi yang sensitif dan mudah terprovokasi terutama oleh ujaran kebencian. Fakta di lapangan mengungkapkan bahwa sepanjang tahun 2017, Kepolisian Republik Indonesia telah menangani 3.325 ribu kasus kejahatan hate speech atau ujaran kebencian.

Peneliti merasa adanya urgensi penelitian untuk menemukan solusi alternatif selain yang sudah dilakukuan oleh penegak hukum dan pemerintah untuk mencegah penyebaran ujaran kebencian terutama saat pemilihan presiden tahun 2019 mendatang yang mungkin salah satunya bisa ditemukan pada peran aktif pemuka agama atau religioun leader dalam kelompok-kelompok agama yang memiliki peran sentral untuk memberikan pemahaman tentang dampak negatif dari ujaran kebencian melalui pola komunikasi yang tepat.

\section{TINJAUAN PUSTAKA}

\section{Pola Komunikasi Kelompok}

Bales mendefenisikan bahwa kelompok adalah sejumlah individu yang berinteraksi dengan sesamanya secara tatap muka atau serangkaian pertemuan. Tiap-tiap anggota tersebut saling menerima impresi atau persepsi anggota lain pada waktu tertentu dan menimbulkan pertanyaan kemudian, yang membuat setiap anggota bereaksi sebagai reaksi individual (Arifin,2015:20).

Komunikasi menurut Onong Uchajana Effendi (dalam Naim, 2011:18) merupakan suatu proses pernyataan antar manusia. Hal yang disampaikan adalah buah pikiran atau perasaan seseorang kepada orang lain dengan menggunakan bahasa sebagai alat penyampainya.
Komunikasi kelompok adalah proses komunikasi yang berlangsung antara 3 orang atau lebih secara tatap muka di mana anggota-anggotanya saling berinteraksi satu sama lain. Tidak ada batasan jumlah anggota yang pasti namun tidak lebih. Sedangkan menurut Onong Uchjana Effendy, komunikasi kelompok ialah komunikasi yang berlangsung antara seorang komunikator dengan sekelompok orang yang jumlahnya lebih dari dua orang dan menimbulkan arus balik secara langsung (Kholil,2011:67).

Komunikasi kelompok sebaiknya dipahami sebagai suatu pola interaksi antar anggota daripada sebagai suatu rangkaian keterampilan khusus. Johnson dalam Derry (2005:57), menyatakan bahwa untuk dapat lebih memahami komunikasi kelompok ada tiga pendekatan yang dapat digunakan untuk mengkajinya yakni:

1) Analisis interaksi digunakan untuk menganalisis interaksi antar anggota kelompok. Pertama, banyaknya dan lamanya sebuah komunikasi. Kedua, pada siapa kite berkomunikasi. Ketiga, siapa yang menggerakan siapa dan dengan cara apa. Umumnya anggota high-authority (atasan) akan lebih mengontrol anggota low authority (bawahan).

2) Hirarki komunikasi satu arah dan dua arah. Komunikasi satu arah merupakan komunikasi yang berlangsung dari satu orang saja yaitu hanya dari pihak komunikator dengan tidak memberikan kesempatan kepada komunikan untuk memberikan tanggapan. sementara komunikasi dua arah adalah komunikasi yang berlangsung antara dua belah pihak da nada hubungan timbal balik baik dari komunikator maupun komunikan. Hirarki komunikasi dapat diartikan sebagai tingkatan arus infomasi.

3) Jaringan komunikasi. Jaringan komunikasi adalah penggambaran "how say to whom" dalam suatu system sosial. Jaringan komunikasi adalah langkah-langkah dalam menentukan siapa yang dapat 
berkomunikasi dan bagaimana komunikasi itu dilakukan ( secara langsung ataupun melalui anggota lain) sehingga dapat diterima antar anggota dalam kelompok dan organisasi. Terdapat beberapa tipe jaringan komunikasi, diantaranya sebagai berikut: Skema Lingkaran, Skema Roda, Skema Y, Skema Rantai dan Skema Semua Saluran

Dengan mengetahui gambaran proses komunikasi maka kita akan mengetahui pola komunikasi yang terjadi di dalam sebuah kelompok, seperti pemimpin sebagai komunikator, anggota sebagai komunikan, bagaimana bentuk penyampaian pesannya,dan lain sebagainya

\section{Pencegahan Penyebaran Ujaran Kebencian}

Menurut Oktavia (2013) upaya pencegahan adalah sebuah usaha yang dilakukan individu dalam mencegah terjadinya sesuatu yang tidak diinginkan. Dalam pengertian yang luas pencegahan diartikan sebagai upaya secara sengaja dilakukan untuk mencegah terjadinyan gangguan, kerusakan, atau kerugian bagi seseorang. Sedangkan menurut Kamus Besar Bahasa Indonesia, penyebaran adalah sebuah proses,cara atau perbuatan yang bertujuan untuk menyebarkan atau membagikan sesuatu (https://kbbi.web.id/sebar).

Secara sederhana, Ucapan / Ujaran kebencian adalah tindakan komunikasi yang dilakukan oleh suatu individu atau kelompok dalam bentuk provokasi, hasutan, ataupun hinaan kepada individu atau kelompok yang lain dalam hal berbagai aspek seperti ras, warna kulit, etnis, gender, cacat, orientasi seksual, kewarganegaraan, agama, dan lain-lain (https://id.wikipedia.org/wiki). Sementara itu Black's Law Dictionary (9 ${ }^{\text {th }}$ Edition) mendefenisikannya sebagai "Speech that carries no meaning other than the expression of hated for some group, such as a particular race, esp in circumstances in which the communications is likely to provoke violence"(ucapan yang tidak memiliki makna lain selain ekspresi kebencian terhadap kelompok tertentu, misalnya: ras, khususnya dalam situasi di mana ekspresi tersebut dapat memacu terjadinya kekerasan).

\section{METODE PELAKSANAAN}

Penelitian ini menggunakan pendekatan penelitian sosial kualitatif dengan rancangan studi kasus. Menurut Lexy J. Moelong (2010 : 6), penelitian kualitatif adalah penelitian yang bermaksud untuk memahami fenomena tentang apa yang dialami oleh subjek penelitian misalnya perilaku, persepsi, motivasi dan tindakan, dll., secara holistik, dan dengan cara deskripsi dalam bentuk kata-kata dan bahasa, pada suatu konteks khusus yang alamiah dan dengan memanfaatkan metode alamiah.

Berdasarkan hal tersebut, maka pada penelitian kualitatif, peneliti memasuki situasi sosial tertentu, melakukan observasi dan wawancara kepada orang-orang yang dipandang tahu tentang situasi sosial tersebut. Penentuan sumber data pada orang yang diwawancarai dilakukan secara purposive, yaitu dipilih dengan pertimbangan dan tujuan tertentu. Menurut Moelong (2010 : 224) purposive sample adalah menggali informasi yang menjadi dasar dari rancangan dan teori yang muncul. Informan utama dalam penelitian ini adalah pemuka agama sebagai pemimpin kelompok dan umatnya sebagai informan tambahan.

\section{HASIL dan PEMBAHASAN}

Fenomena ujaran kebencian terus mengalami peningkatan menjelang waktu pemilihan presiden 2019. Data dilapangan mencatat adanya kenaikan yang cukup signifikan terutama di bulan Januari dan Februari. Sebanyak 175 konten hoaks dan ujaran kebencian yang berhasil diverifikasi oleh Tim AIS Kemkominfo. Angka ini naik dua kali lipat di bulan Februari 2019 menjadi 353 konten dan terus meningkat menjadi 453 konten selama Maret 2019. Konten -konten tersebut berisi isu politik, isu kesehatan, isu pemerintahan, hoaks berisikan fitnah terhadap individu tertentu, terkait kejahatan, isu agama, internasional serta isu pendidikan (https://kabar24. 
bisnis.com/read/20190401/15/906705/jel ang-pemilu-2019-hoaks-dan-ujaran kebencian-meningkat).

Ketika tindakan represif dan upaya penegakan hukum di anggap tidak cukup untuk menyelesaikan persoalan maraknya ujaran kebencian maka pendekatan melalui komunikasi kelompok dapat menjadi salah satu strategi pencegahan penyebaran ujaran kebencian terutama pada pemilihan presiden tahun ini. Mengapa harus melalui pendekatan kelompok sebab secara alamiah manusia adalah mahluk sosial yang memerlukan hidup berkelompok-kelompok selain sebagai reaksi terhadap keadaan lingkungan juga sebagai naungan rasa aman di antara mereka.

Melalui proses komunikasi, pendekatan pemimpin kelompok kepada setiap anggota nya dapat dilakukan menggunakan cara-cara persuasive agar setiap anggotanya mau melakukan atau tidak melakukan sesuatu. Pendekatan melalui komunikasi kelompok ini dapat diaplikasikan untuk mencegah penyebaran ujaran kebencian dalam bentuk apapun terutama pada pemilihan presiden tahun ini. Hal tersebut dapat kita lihat dari bentuk pola komunikasi yang terdapat dalam kelompok tersebut.

Pola komunikasi dapat dipahami sebagai pola hubungan antara dua orang atau lebih dalam pengiriman dan penerimaan pesan dengan cara yang tepat sehingga pesan dapat dipahami oleh penerima. Ada tiga pendekatan yang dapat digunakan untuk menguji pola komunikasi yakni analisis interaksi, arus komunikasi serta jaringan komunikasi dalam kelompok.

\section{Analisis Interaksi}

Sebagai mahluk sosial, manusia senantiasa saling berinteraksi dengan orang lain. Adanya interaksi membuat manusia berkelompok satu sama lainnya. Kohesivitas sebuah kelompok dapat dipertahankan dengan cara menjaga komunikasi yang baik antara pemimpin kelompok, pengurus dan dengan sesama anggota. Lamanya interaksi komunikasi sangat berpengaruh terhadap kelangsungan kelompok. Semakin sering individu dalam kelompok melakukan komunikasi, maka akan semakin erat hubungan antar anggota yang tercipta dan semakin solid kelompok tersebut.

\section{A. Intensitas Komunikasi}

Dalam komunikasi kelompok, segala sesuatu yang akan disampaikan oleh individu atau kelompok kepada anggotanya memiliki maksud dan tujuan yang berbedabeda. Oleh karena itu setiap kelompok memiliki waktu penyampaian yang berbeda. Tujuan utama terjadinya proses intensitas komunikasi yaitu membantu seseorang meningkatkan efektivitas pribadi dan efektivitas antar pribadinya. Intensitas komunikasi sangat penting dalam menumbuhkan budaya keterbukaan dan menanamkan rasa saling percaya antara sesama anggota kelompok. Setiap kelompok memiliki jadwal pertemuan yang dibuat secara rutin oleh pengurus rumah ibadah agar jama'ah /jemaat dapat datang beribadah sekaligus bersosialisasi dengan sesama anggotanya. Kelompok agama Hindu di Pura Agung Raksa Bhuana melakukan darma wacana dua kali dalam sebulan yakni saat purnama ( bulan terang) dan tilem (bulan mati), Kelompok agama budha di Vihara Sinar Budha melaksanakan kebaktian khusus pada saatCe It dan Cap Go ( tanggal 1 dan 15 dalam penanggalan kalender Imlek), kelompok Umat Kristen di GKPS Hang Tuah sendiri melakukan kebaktian pada hari minggu sementara untuk pendalaman Alkitab dilaksanakan pada hari selasa dan sabtu pukul 08.00 pagi. Kelompok Umat Islam yang beribadah di Mesjid Agung Medan mendengarkan kajian atau ceramah setelah ba'da zuhur setiap harinya.

\section{B. Materi atau Isi pesan}

Komunikasi dapat menjembatani segala bentuk ide dan gagasan yang akan disampaikan seseorang. Dalam setiap melakukan komunikasi unsur penting diantaranya adalah pesan. Pesan dapat dimengerti dalam beberapa unsur, salah satunya adalah isi pesan. Isi pesan adalah bahan atau materi yang dipilih dan ditentukan oleh komunikator untuk 
menyampaikan maksudnya kepada komunikan.

Dalam kelompok agama, setiap jadwal pertemuan biasanya diisi dengan penyampaian materi. Pesan yang disampaikan oleh pemuka agama tidak hanya tentang agama, namun juga mencakup bidang sosial, ekonomi bahkan juga masalah politik seperti yang sedang dialami oleh bangsa Indonesia saat ini menjelang Pilpres 2019. Pesan di sampaikan dengan nuansa mendidik dan berisi materi pencerahan yang meliputi pencerahan spiritual, intelektual, emosional, dan multikultural.

Seperti yang disampaikan oleh, Pembina umat hindu, bapak Antoni sembiring bahwa "materi (darma wacana) disesuaikan dengan keadaan saat ini, misalnya ketika di media sosial banyak berita hoax dan ujaran kebencian, maka harapan kami, umat hindu menghindarinya. jadi darma wacana disesuaikan dengan tema di hindu seperti tema hari raya nasional kami saat ini melalui caturbratanevi kita sukseskan pemilu 2019".

Hal yang sama juga disampaikan oleh ibu eva salah satu jemaat GKPS Hang Tuah bahwa "saat berkhutbah tidak hanya tentang agama saja, pendeta menjabarkan contoh-contoh kehidupan.

Dari dua pernyataan informan diatas di simpulkan bahwa isi pesan atau materi yang disampaikan oleh pemuka agama diutamakan berupa nasihat, pengetahuan yang mengarah kepada kebaikan dan persatuan bangsa namun tetap didasari atas pengetahuan keagamaan yang memadai dan bersumber dari ajaran pokok agama. Kesimpulan ini diperkuat oleh pernyataan dari ustad Azwir bahwa

"ketika ada masalah (misalnya perbedaan pendapat) maka kembalikanlah kepada Alquran, jadi di dalam Alquran ada jawaban lengkap dari segala masalah".

\section{Tujuan berkomunikasi}

Sebagai pemimpin kelompok, seorang pemuka agama mempunyai tujuan dalam berkomunikasi diantaranya adalah menciptakan pemahaman dan komitmen pada tujuan utama diturunkannya agama, yaitu melindungi harkat dan martabat kemanusiaan, serta menjaga kelangsungan hidup dan perdamaian umat manusia. seperti yang disampaikan oleh salah satu jemaat GKPS Hang tuah, Ibu eva bahwa

$\begin{array}{ccr}\text { "ketika } & \text { khutbah, } & \text { pendeta } \\ \text { jugamengingatkan } & \text { jemaatnya } & \text { untuk }\end{array}$ menjauhi ujaran kebencian. kita harus ada kasih, harus saling menyayangi. jika ada keburukan cukup kita yang tahu. kita harus perbaiki yang benar yang salah kita luruskan".

Sejalan dengan pernyataan diatas, pak mukhlis selaku jama'ah masjid raya medan juga menyampaikanbahwa

" tujuan pak ustad, berceramah tidak saja hanya membahas masalah tafsir dan tauhid, namun juga tentang menghargai antar umat beragama."

Dengan demikian tujuan akhir dari komunikasi dalam kelompok adalah terjadinya kesamaan makna antara anggota kelompok untuk menghargai umat beragama lainnya.

\section{Arus Komunikasi Kelompok Agama di Kecamatan Medan Polonia.}

Berdasarkan hasil wawancara yang dilakukan oleh peneliti, terdapat beberapa perbedaan arus komunikasi yang dilakukan oleh masing-masing kelompok agama yang terdapat di Kecamatan Medan Polonia. Seperti yang disampaikan oleh ibu Lasmaria, seorang penginjil wanita yang bertugas di GKPS Hang tuah, beliau menyampaikan bahwa

"ketika ibadah di hari minggu, jemaat hanya mendengarkan khotbah dari pendeta. sedangkan untuk sesi sharing dan berdiskusi antara pendeta dengan jemaat biasa dilakukan saat PA ( pendalaman alkitab)".

Hal yang sama juga diungkapkan oleh bapak Hariyono, salah satu Pembina gama hindu yang bertugas di Pura Agung Raksa Bhuanabahwa

"saat ibadah yang dipimpin panindita kami hanya beribadah, setelah itu baru darma 
wacana yang dibawakan oleh pembina. saat darma wacana inilah sharing dan diskusi dapat dilakukan.

Pernyataan informan diatas dapat disimpulkan bahwa kelompok agama hindu dan Kristen menggunakan komunikasi satu arah dan dua arah.

Sedangkan dalam kelompok agama Islam, arus komunikasi yang dilakukan hanya bersifat dua arah, dimana komunikasi yang berlangsung antara pemuka agama dengan jama'ahnya berlangsung timbal balik, seperti yang disampaikan oleh pak Mukhlis bahwa "saat ceramah atau kajian berlangsung, Jemaah diperkenankan untuk bertanya dan kemudian dijawab oleh pak ustad". Sementara pada kelompok agama Budha, komunikasi dilakukan hanya satu arah saja, yaitu dari biksu kepada umat budha. seperti yang disampaikan oleh ibu lilis, selaku pengurus vihara bahwa "disini murni hanya untuk ibadah".

Dengan adanya komunikasi dua arah di dalam kelompok sebenarnya memberikan keuntungan tersendiri. Selain menimbulkan kepuasan diantara kedua belah pihak, informasi yang diterima menjadi lebih jelas dan dipahami, lebih akurat dan lebih tepat karena diperoleh langsung penjelasannya secara lebih detail berbeda dengan komunikasi satu arah yang hanya dilakukan oleh komunikator kepada komunikan secara satu arah, sehingga bisa dikatakan sebagai komunikasi yang tidak memberi kesempatan kepada komunikannya untuk memberi tanggapan, bertanya ataupun menyanggah.

\section{Jaringan Komunikasi Kelompok Agama di Kecamatan Medan Polonia}

Jaringan komunikasi merupakan sebuah jaringan dalam suatu sistem sosial yang terdiri dari individu-individu yang saling berhubungan, yang di hubungkan oleh arus komunikasi yang terpola. Jaringan dalam komunikasi kelompok dapat mengatur arus informasi, menyatukan orang-orang dengan minat yang sama, membentuk penafsiran yang sama dan lain sebagainya. Berdasarkan hasil pengamatan dan wawancara yang peneliti lakukan, setiap kelompok agama memiliki jaringan komunikasi yang berbeda-beda. Dilihat dari bentuknya terdapat beberapa tipe jaringan komunikasi diantaranya sebagai berikut:

Dalam kelompok agama Hindu jaringan komunikasi dengan skema $Y$ sangat berpengaruh besar dalam mempertahankan kelompok agar tetap kompak dan tidak terpecah belah. Jadi proses filter informasi dilakukan terlebih dahulu oleh pemimpin kelompok kemudian baru informasi disampaikan kepada umat. Kelompok agama hindu memiliki dua religious leader, yang pertama adalah panindita sebagai pemimpin upacara ritual keagamaan dan yang kedua adalah Pembina sebagai pemimpin dalam pemberian darma wacana. Dengan adanya jaringan komunikasi skema Y para anggota merasa nyaman berada di dalam kelompok.

Ustadz sebagai pemimpin kelompok menjadi fokus perhatian pada kelompok agama Islam yang menerapkan skema roda. Pemimpin dapat mengirim dan menerima pesan dari semua anggota kelompok. Keberhasilan komunikasi pada skema ini lebih baik daripada tipe rantai, karena informasi yang disampaikan langsung oleh satu sumber informasi sehingga penyimpangan isi pesan dapat dikurangi. Interaksi yang terjadi antara pemimpin dengan anggota kelompok secara langsung membuat para anggota dapat meminta saran dan masukan dari pemimpinnya. Skema ini lah yang memunculkan rasa kekeluargaan yang kuat antar sesama anggota kelompok.

Sementara itu kelompok agama Budha dan kelompok agama Kristen menerapkan skema rantai. Berdasarkan hasil wawancara antara peneliti dengan pengurus Vihara Sinar Budha, diketahui bahwa arus komunikasi yang terjadi di dalam kelompok agama budha adalah komunikasi satu arah, jadi kegiatan seperti diskusi ataupun sharing dengan pemuka agama (Biksu) jarang dilakukan, jika ada komunikasi hanya sebatas masalah ibadah dan harus meminta izin terlebih dahulu

Hal ini berbanding terbalik dengan kelompok agama Kristen, dengan skema 
yang sama, komunikasi dua arah terkadang terjadi didalam kelompok ini meskipun tidak setiap saat dan ada batasan waktunya. Dalam kelompok agama Kristen terdapat empat religious leader didalam struktur organisasi gereja yang masing-masing memiliki tanggung jawab untuk membina umat. Jadi, meskipun jaringan komunikasi berbentuk skema rantai tetap saja ada kebebasan dalam berkomunikasi didalam kelompok tersebut, hal inilah yang kemudian membuat Jemaat gereja GKPS Hang tuah merasa nyaman berada di dalam kelompok ini.

\section{Proses Komunikasi Kelompok Agama dalam Pencegahan Penyebaran Ujaran Kebencian.}

Berdasarkan pengamatan dan analisa yang sudah dilakukan peneliti terkait pola komunikasi dan proses komunikasi yang dilakukan selama ini oleh pemimpin kelompok kepada anggotanya maka dibawah ini dapat dijelaskan bahwa peran pemimpin kelompok sangat mempengaruhi dalam proses penyebaran ujaran kebencian atau pencegahan ujaran kebencian walaupun beberapa kelompok dipengaruhi oleh komunikasi antar anggota.

\section{A. Pola dan Proses Komunikasi Kelompok Agama Islam Terhadap Pencegahan Penyebaran Ujaran Kebencian.}

Berdasarkan pola komunikasi yang sudah dijabarkan di alinea sebelumnya bahwa kelompok agama islam menjadikan pemimpin kelompok sebagai pusat dari informasi keagamaan selain itu karena arus komunikasi berlangsung dua arah memberikan kesempatan kepada anggota kelompok untuk meminta nasihat dan juga pendapat mengenai suatu perkara atau masalah.

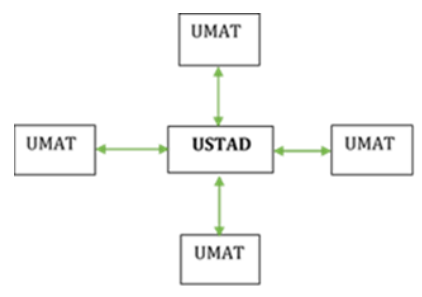

Gambar 1. Pola Komunikasi Kelompok Agama Islam bertipe Roda
Hal inilah yang sebenarnya dapat dimanfaatkan oleh pemuka agama untuk mempengaruhi sikap dan perilaku anggotanya. Termasuk dalam masalah penanganan ujaran kebencian menjelang pemilihan presiden 2019 yang banyak meresahkan umat beragama belakangan ini. Jadi proses pencegahan ujaran kebencian sangat dipengaruhi oleh kredibilitas seorang pemimpin kelompok sebab apa yang disampaikan oleh pemimpin kelompok dengan pola komunikasi skema roda akan di dengar oleh anggotanya. Seperti apa yang disampaikan oleh Ustad A selaku pemimpin kelompok agama Islam di Mesjid Agung dalam salah satu ceramahnya bahwa

"ujaran kebencian itu di dalam islam hukumnya haram dan tidak dibenarkan melakukan itu. maka dari itu ketika ada berita dari orang fasik maka kita harus tabayun terlebih dahulu. cari tahu terlebih dahulu berita itu darimana. kalo tidak benar jangan kita sampaikan".

Dari hasil wawancara dengan salah satu jama'ah yang pernah mengikuti kajian atau ceramah dari Ustad di Mesjid Agung Medan, didapat kesimpulan bahwa memang benar adanya bahwa informasi atau pesan yang disampaikan oleh pak ustad selalu diingat oleh jama'ahnya termasuk tentang cara mencegah penyebaran ujaran kebencian di tahun politik saat ini. Dalam wawancara tersebut pak mukhlis selaku jama'ah mengungkapkan bahwa

"cara saya menyikapi ujaran kebencian, secara pribadi saya ikut apa kata ulama saja. Misalnya seperti kasus kemarin itu (ujaran kebencian menjelang pilpres), jadi apa yang ustad sampaikan saya ikut saja"

Pernyataan tersebut menjelaskan bahwa terdapat expert power dari seorang religious leader sebagai pemimpin kelompok. Namun yang menjadi masalah adalah ketika pemuka agama mengambil sumber rujukan yang kontroversial di masyarakat. seperti yang dilakukan oleh Ustad A di Mesjid Agung yang mengambil rujukan dari tokoh yang kontroversial, Rocky Gerung. Dimana dalam wawancara, beliau menyampaikan "ujaran kebencian 
saat ini menjadi kesenangan bagi sebagian. Saya terus terang bahwa negarapun saat ini melakukan ujaran kebencian, tidak tanggung-tanggung. Seharusnya Negara yang mendidik. seperti kata rocky gerung yang paling hoax adalah Negara.Jadi harusnya Negara yang mendidik kita semua. ini sudah salah jalan".

Jika dipahami pernyataannya, maka ujaran kebencian dianggap pemuka agama tersebut lebih banyak dilakukan oleh Negara dengan mengutip informasi dari Rocky Gerung yang terkenal di media massa sebagai tokoh kontroversial bahwa "yang paling Hoax adalah Negara". Hal ini dapat menimbulkan kesalahpahaman persepsi di tengah anggota kelompok dalam menilai Negara. Pernyataannya bukan mendamaikan umat tetapi cenderung memprovokasi umat untuk membenci Negara. Seharusnya sebagai pemuka agama, ia menjadi penyejuk umat dan memberikan informasi yang jelas tentang cara yang tepat melakukan "tabayyun". Oleh karena itu dibutuhkan pengawasan dan pembinaan agar pengajaran keagamaan dalam penerapan kehidupan berbangsa dan bernegara tetap pada koridor yang benar sehingga toleransi antar umat beragama tetap terjaga.

\section{B. Pola dan Proses Komunikasi Kelompok Agama Hindu Terhadap Pencegahan Penyebaran Ujaran Kebencian.}

Dalam kelompok agama Hindu, jaringan komunikasi dengan skema $\mathrm{Y}$ sangat berpengaruh besar dalam meningkatkan kohesi kelompok tersebut.

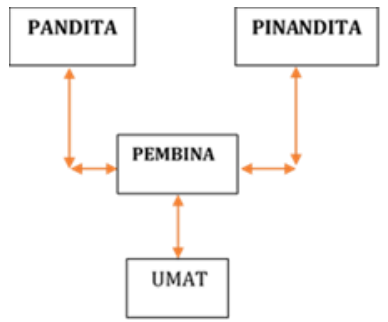

Gambar 2. Pola Komunikasi Kelompok Agama Hindu bertipe $Y$

Hal ini terlihat dari hasil wawancara peneliti dengan salah satu pembina umat Hindu bapak Antoni sembiring, dimana ketika membahas tentang fenomena ujaran kebencian yang belakangan ini semakin banyak menjelang pemilihan presiden 2019. Beliau dengan tegas menyampaikan bahwa

"kami sepakat, kalo memang ini sifatnya ujaran kebencian yang nantinya akan menimbulkan perpecahan maka kami antisipasi. Stop tidak usah ikut menyebarkan yang penting bagaimana kita menjadi manusia yang nasional artinya ayo kita sama-sama menjaga keutuhan NKRI kita ini.

Hal senada juga disampaikan oleh Bapak Jumadi, bahwa:

"perbedaan pilihan itu biasa, jadi udah daripada umat hindu pecah bahkan NKRI pecah lebih baik silahkan memilih mana yang sesuai dengan kata hati yang penting tidak menimbulkan perpecahan".

Himbauan atau pesan untuk menjauhi ujaran kebencian tidak hanya disampaikan oleh pembina umat hindu pada saat pertemuan tatap muka saja tetapi komunikasi juga terjadi melalui komunikasi virtual menggunakan aplikasi WA, seperti yang dijelaskan oleh pak Hariyono, bahwa

"kami punya grup WA, khusus untuk warga kami. Melalui media itulah kami sampaikan pesan-pesan itu terutama ketika berita itu sangat santer (viral) dan sangat menggangu".

Pemimpin kelompok dalam jaringan komunikasi skema Y memang mempunyai pengaruh yang kuat dalam proses menjaga kekompakan kelompok. Tidak hanya satu pemimpin, kelompok dengan skema $\mathrm{Y}$ memiliki dua pemimpin (Panindita dan Pembina) yang artinya proses filterisasi informasi terjadi dalam dua tahapan. Jadi, peran pemimpin tidak saja mengarahkan perilaku anggota kelompok sesuai dengan tujuan kelompok, melainkan harus tanggap terhadap segala perubahan yang terjadi dalam kelompoknya sebagai akibat dari perkembangan kegiatan kelompok dan usaha tersebut memang sangat terlihat pada beberapa kalimat penegasan seperti yang diucapkan oleh Pak Jumadi bahwa 
"Jangan sampai umat Hindu sendiri terpecah belah hanya gara-gara pilpres, pilkada dan pileg. mari kita saling menghargai."

\section{Pola dan Proses Komunikasi Kelompok Agama Kristen Terhadap Pencegahan Penyebaran Ujaran Kebencian.}

Jaringan komunikasi pada skema rantai terkesan otoriter namun tidak pada Kelompok Agama Kristen karena meskipun skema rantai namun arus komunikasinya bersifat dua arah dan lebih terbuka.

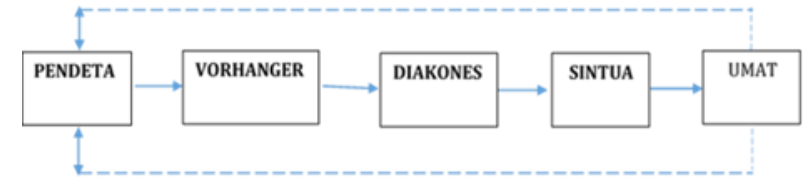

Gambar 3. Pola Komunikasi Kelompok Agama Kristen bertipe Rantai

Dengan empat orang religious leader dalam struktur organisasi gereja,membuat anggota kelompok semakin kuat dan kompak terutama dalam menyikapi ramainya ujaran kebencian menjelang pemilihan presiden tahun ini. Seperti yang disampaikan oleh salah satu jemaat GKPS Hang Tuah, ibu Eva Sibarani, bahwa

"pendeta selalu menghimbau dan mengingatkan agar kami(jemaat) tidak menebar kebencian karena itu bukan kasih. Kami harus menyayangi. Jika dia ada keburukan ya cukup kami yang tahu.Bahkan selalu kami bawakan dalam doa syafaat agar negara ini tetap damai".

Hal yang sama juga diungkapkan oleh Sintua Lasmaria, selaku Pembina umat Kristen, bahwa :

"ketika ada kebencian-kebencian diluar sana ya tentunya kita harus berbeda dengan mereka. orang yang memiliki agama itu harus berbeda dengan orang yang tidak menekuninya. apalagi dalam ajaran Kristen itu ada yang namanya kasih. tidak memperuncing dan memperkeruh suasana serta tidak memperpanjang persoalan. Firman tuhan mengajarkan tentang kebaikan dan tidak pernah membalas kebaikan dengan kejahatan atau kejahatan itu dengan kejahatan".
Dari hasil wawancara diatas dapat disimpulkan bahwa pemimpin kelompok agama Kristen berperan aktif mengajak jemaatnya untuk tetap tenang dan tidak ikut memperkeruh suasana terutama menjelang pemilihan presiden. Himbuan tersebut dilakukan sebab pemimpin memiliki tanggung jawab terhadap masa depan kelompoknya agar tetap berjalan sesuai dengan ajaran agama yang terdapat didalam nats atau ayat-ayat alkitab.

\section{Pola dan Proses Komunikasi Kelompok Agama Budha Terhadap Pencegahan Penyebaran Ujaran Kebencian.}

Berdasarkan hasil wawancara antara peneliti dengan pengurus vihara sinar budha, diketahui bahwa komunikasi yang terjadi di dalam kelompok agama budha adalah komunikasi satu arah, jadi kegiatan seperti diskusi ataupun sharing dengan pemuka agama tidak pernah dilakukan, jika ada komunikasi hanya sebatas masalah ibadah.

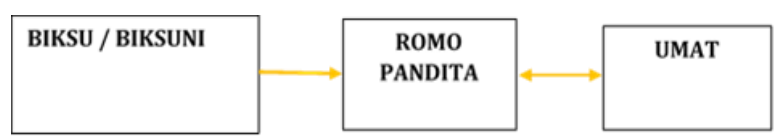

Gambar 4. Pola Komunikasi Kelompok Agama Buddha bertipe Rantai

Tidak banyak data, yang bisa peneliti gali dari kelompok agama budha. Dari beberapa kunjungan resmi yang peneliti lakukan, penolakan demi penolakan terjadi, tanpa tahu alasan yang jelas. Sampai pada suatu titik, Ibu lilis selaku pengurus Vihara Sinar Budha sedikit memberi statement bahwa "disini kami hanya murni kebaktian, mendekatkan diri kepada budha. tidak ada membahas yang lain". Pengurus vihara Sinar Budha sangat tertutup, tidak memberikan kemudahan akses peneliti untuk bertemu dengan religious leader mereka dan sangat membatasi diri dari orang yang bukan kelompoknya.

\section{SIMPULAN}

Proses komunikasi dalam kelompok yang dilakukan oleh religious leader terhadap Jama'ah / Jemaatnya memiliki pemahaman yang jelas tentang pencegahan penyebaran ujaran kebencian. Himbauan 
untuk tidak ikut memperkeruh suasana terutama menjelang pemilihan presiden danuntuk tetap menjauhi ujaran kebencian dikomunikasikan tidak hanya melalui pertemuan tatap muka namun juga melalui komunikasi secara virtual menggunakan WhatApp.

1. Pola komunikasi kelompok agama dalam pencegahan penyebaran ujaran kebencian berbeda-beda dalam setiap kelompoknya. Kelompok Agama Hindu cenderung memiliki jaringan komunikasi yang relatif tertutup dalam hal politik untuk menghindari perpecahan sesama umat hindu dan menghimbau kelompoknya untuk lebih meningkatkan perasaan saling menghargai. Sementara kelompok Agama Budha dalam proses ibadahnya tidak menyinggung masalah politik dan lebih membahas masalah keamanan dan perekonomian. Jaringan komunikasi yang lebih terbuka dan aktif lebih terlihat dalam kelompok Agama Kristen yang sangat mengakomodir perkembangan kelompoknya dalam menghadapi banyaknya ujaran kebencian yang beredar di media sosial, misalnya dengan memanfaatkan aplikasi whatsapp, dan dibahas dalam kelompok doa. Sementara jaringan komunikasi dalam kelompok Agama Islam,menjadikan pemuka agama sebagai filter dalam menyaring pesanpesan yang berisikan ujaran kebencian sehingga bagi kelompoknya pemuka agama menjadi panutan / patron untuk bersikap.

\section{DAFTAR PUSTAKA}

\section{Buku:}

Arifin, Bambang S.2015.Dinamika Kelompok.Pustaka Setia:Bandung

Black's Law Dictionary $9^{\text {th }}$ ed (West Group,2009), Bryan A.Gerner, editor, ISBN 0-314-19949-7

Derry, Sharon J.dkk.2005.Interdisciplinary Collaboration: an Emerging Cognitive Science. New Jersey: Lewrence Erlbaum
Kholil, Syukur.2011.Teori Komunikasi Massa. Citapustaka Media Perintis: Bandung

Moleong, Lexy J.2010.Metodologi Penelitian Kualitatif. Bandung: Remaja Rosdakarya

\section{Internet:}

Ucapan

Kebencian. https://id.wikipedia.org/wiki/Ucapan_kebe ncian.tanggal akses 18 Agustus 2018.

Jatmiko,Leo Dwi. https://kabar24.bisnis.com/read/2019040 1/15/906705/jelang-pemilu-2019-hoaksdan-ujaran-kebencian-meningkat. Tanggal diakses,24 Juli 2019

Oktavia,Y. 2013.Kesehatan dalam teori.http://www.rstarakanjakarta.com/20 13/05/cara-pencegahan-penyakit-yangbenar-dan-tepat/). Tanggal diakses, 20 Agustus 2018. 